\title{
Metrics of perineal support (MOPS) study
}

\author{
Vladimir Kalis ${ }^{1,2}$, Zdenek Rusavy ${ }^{1,2}$, Linda Havelkova ${ }^{3}$, Tomas Zitka ${ }^{3}$, David Tolar ${ }^{3}$ and Khaled M. Ismail ${ }^{1,2^{*}}$
}

\begin{abstract}
Background: Manual perineal protection (MPP) is an intrapartum intervention suggested to protect perineal integrity during childbirth. Proper execution of MPP is complex and evaluation of its true contribution is difficult in the clinical setting because of the large number of obstetric variables, some of which are hardly quantifiable. In this study we aimed to gather initial data on the forces executed by the accoucheur's thumb, index and middle fingers during MPP at the time of fetal head expulsion, quantify the duration of the intervention and investigate the timely interaction of the different components of MPP.
\end{abstract}

Methods: Two bespoke right-handed measurement gloves (MG), with built in sensors, were designed and produced. The MG allowed the electronic real-time measurement of applied forces during MPP and transferred this data wirelessly to an integrated computer system. Sterile gloves were worn over the MG when used at the time of birth. The study was undertaken between January and December 2019. Singleton, term pregnant women having their first vaginal birth who provided a valid written consent were enrolled into this prospective pilot study. All deliveries were undertaken by one of two obstetricians experienced in MPP.

Results: Twenty women were enrolled. The mean duration of execution of MPP during the last contraction was $13.6 \mathrm{~s}$. In $20 \%$ it lasted $<5 \mathrm{~s}$. The overall mean values of the average and maximum forces of the thumb, index and middle fingers were $26.7 \mathrm{~N} ; 25.5 \mathrm{~N} ; 20.2 \mathrm{~N}$ and $34.3 \mathrm{~N} ; 32.6 \mathrm{~N}$; and $27.6 \mathrm{~N}$ respectively. The onset of fingers and thumb activity was simultaneous in 13 cases (65\%), while in seven (35\%) deliveries the middle finger's force activity was initiated later.

Conclusions: MPP during fetal head expulsion happens over a short period of time. In the majority of cases the thumb and fingers actions started simultaneously. There were differences in the duration of application and the forces executed by the fingers and thumb between the two practitioners, however this was only significant for thumb measurements. The results obtained will aid in improving further MPP modeling studies to optimize the technique.

Keywords: Keys: Manual perineal protection, Physiology, Vaginal delivery, Computational modelling, Finnish method, Pressure, Forces, Duration, Variability

\section{Background}

Birth-related perineal trauma can be a cause of longstanding significant adverse effect on a woman's quality of life [1-3]. Manual perineal protection (MPP) was historically suggested to protect the integrity of the perineum during fetal head expulsion [3-6]. However, more recent RCTs

\footnotetext{
* Correspondence: khaled.ismail@lfp.cuni.cz

'Department of Gynecology and Obstetrics, University Hospital, alej Svobody 76, 30460 Pilsen, Czech Republic

${ }^{2}$ Biomedical Center, Faculty of Medicine in Pilsen, Charles University, Pilsen, Czech Republic

Full list of author information is available at the end of the article
}

brought doubts as to its real effectiveness in reducing such trauma $[7,8]$. In contrast, larger well-designed prospective studies have consistently shown a significant positive contribution of MPP to preserve perineal integrity and reduce risk of high order tears [9-16].

Effective MPP is a complex procedure to execute [17-21]. Indeed, a recent survey of practitioners from units that support a routine MPP policy demonstrated that only $5.6 \%$ of respondents were able to provide a comprehensive description of MPP correctly $[18,19]$. The Finnish technique of MPP (FMPP) involves application of the thumb and index finger of the dominant

(c) The Author(s). 2020 Open Access This article is licensed under a Creative Commons Attribution 4.0 International License, which permits use, sharing, adaptation, distribution and reproduction in any medium or format, as long as you give appropriate credit to the original author(s) and the source, provide a link to the Creative Commons licence, and indicate if changes were made. The images or other third party material in this article are included in the article's Creative Commons licence, unless indicated otherwise in a credit line to the material. If material is not included in the article's Creative Commons licence and your intended use is not permitted by statutory regulation or exceeds the permitted use, you will need to obtain permission directly from the copyright holder. To view a copy of this licence, visit http://creativecommons.org/licenses/by/4.0/ The Creative Commons Public Domain Dedication waiver (http://creativecommons.org/publicdomain/zero/1.0/) applies to the data made available in this article, unless otherwise stated in a credit line to the data. 
hand on the perineal skin anterolateral to the fourchette and their approximation to reduce midline perineal strain. The flexed middle finger is used to apply pressure against the perineal body to facilitate the process of fetal head extension. While, the non-dominant hand controls the speed of fetal head expulsion and facilitates fetal head extension $[18,19]$. Practically, it is difficult to evaluate the actual contribution of the individual components of FMPP in a clinical setting, because of a high number of confounders and obstetric variables, some of which are hardly quantifiable. Moreover, a proper timely execution of this procedure is challenging since the process of fetal head expulsion happens during a relatively short and critical time.

To overcome the difficulties of real-life clinical evaluation, a simplified computational finite elements model has been used as surrogate $[17,20,21]$. This has enabled to optimize the placement and direction of movement of the different components of FMPP that was associated with the lowest degree of perineal strain $[17,20,21]$. Nonetheless, computational modeling studies are limited by the lack of realistic information about the actual duration of active MPP, the dynamic timeline of when the different individual components are utilized in an actual birth and the forces applied at their execution. We believe that understanding such parameters would improve the precision of future computational modeling and provide objective means to refine the technique further. Therefore, in this study we aimed to gather initial data on the forces executed by the accoucheur's thumb, index and middle fingers at the time of MPP, quantify the precise duration of the intervention, investigate the timely interaction of the different components of MPP and explore the degree of intra and inter-practitioner variability in the above variables.

\section{Methods}

For the purpose of this study, two bespoke identical righthanded measurement gloves (MG) were designed and produced at New Technologies - Research Centre, University of West Bohemia, Pilsen, Czech Republic Fig. 1.

MG is an electronic measurement device allowing the measurement of forces applied during MPP. It is part of an integrated measurement system, which collects, transfers and archives measurement data on a wirelessly connected PC. The glove has three force sensing elements located in pre-selected positions relating to points on the accoucher's dominant hand, which are in contact with maternal perineum and exert the main pressure force at the time of MPP. The MG and its data acquisition system were designed to the highest standards for safety and durability. The glove is powered by a miniature $3 \mathrm{~V}$ lithium cell battery and uses a wireless low power data transmission with the electronics electrically isolated from the glove user and the touched surface.
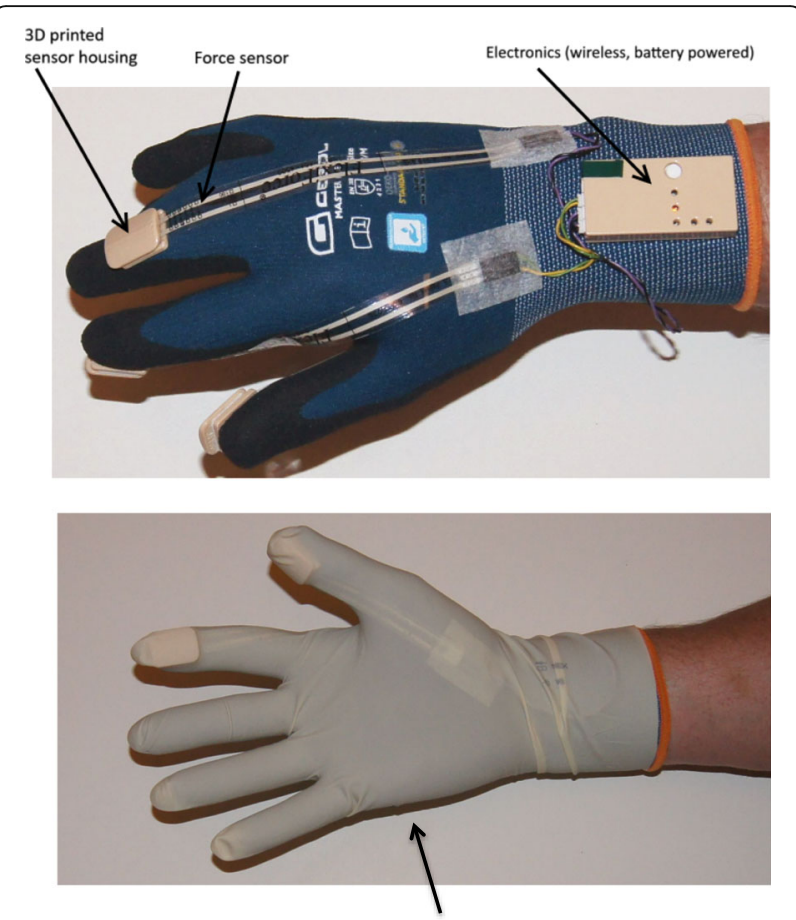

MG covered with a sterile surgical glove

Fig. 1 The measurement glove

Before each use the glove was covered by disposable sterile surgical glove. The MG's built-in force sensors (Tekscan, Inc., 307 West First Street South Boston, MA 02127, US) have a maximum allowed force application of $100 \mathrm{~N} /$ sensor with a frequency acquisition of 100 samples per second. The system was made very simple to operate with.

Measured data were transferred wirelessly at the 2.4 $\mathrm{GHz}$ ISM (industrial, scientific and medical) frequency band. The used communication protocol is compliant with IEEE 802.15.4 standard providing high reliability of data transmission. Used wireless communication method was verified in a previous medical sensor project and was proven safe for use in medical sensors located in close proximity to the human body [22].

Following several test measurements on a childbirth simulation model, the clinical measurements were performed on the labor ward of a tertiary perinatology care unit, department of Gynecology and Obstetrics, University Hospital, Pilsen, Czech Republic. Woman at term having their first spontaneous vaginal birth with good understanding of Czech language and who signed a valid consent were considered eligible for the study. The local Ethics committee approved this study on October 4, 2018 and all women signed an informed consent.

At the time of birth, the accoucher wore the MG, which was completely covered by a surgical sterile glove. Signal from the sensors was filtered by low-pass 
Buttherworth filter with a cut-off frequency of $1 \mathrm{~Hz}$ to remove noise. The course of the whole end of the second stage of labor was recorded. Simultaneous voice recording was done to avoid error in data interpretation. Data from the last contraction, the fetal head expulsion, were evaluated and compared.

Inter-individual variations in applied forces were evaluated with non-parametric ANOVA (2-sample KruskalWallis test) using Python 3.7 and SciPy 1.1.0 statistical package. The cut-off for statistical significance was set at $p<0.05$. For intra-individual differences, we relied on standard deviations and interquartile ranges to describe the variation.

\section{Results}

Between January 1 and December 31, 2019 two experienced obstetricians, actively involved in delivering MPP structured training, attended 20 term first vaginal deliveries (10 VK and $10 \mathrm{ZR})$. Full data were available from all measurements. There were no operative vaginal deliveries or episiotomies performed in this cohort. None of the study participants sustained obstetric anal sphincter injuries at the time of birth. The demographic data and obstetric variables of the cohort are presented in Table 1.

The mean duration of execution of MPP at the time of fetal head expulsion was $13.6 \mathrm{~s}$, the overall mean values of the average forces of the thumb, index and middle fingers were $26.7 \mathrm{~N} ; 25.5 \mathrm{~N}$; and $20.2 \mathrm{~N}$ while the means of maximum forces were: $34.3 \mathrm{~N} ; 32.6 \mathrm{~N}$; and $27.6 \mathrm{~N}$ respectively (Table 2). In 13 cases (65\%) the activity of all digits started simultaneously while in seven $(35 \%)$ deliveries the middle finger's activity was initiated later. However, in only three (15\%) cases this delay was longer than $1 \mathrm{~s}$.

There were statistically significant differences in the mean $(p=.008)$ and maximum $(p=.03)$ thumb forces between the two obstetricians. However, the differences in MPP duration and forces executed by the index or middle fingers remained non-significant despite the

Table 1 Obstetric data of the study group

\begin{tabular}{lll}
\hline $\begin{array}{l}\text { Procedure } \text { - independent } \\
\text { characteristics }\end{array}$ & $\begin{array}{l}\text { Median } \\
\text { (range 25-75\%) }\end{array}$ & Mean \pm SD \\
\hline Maternal age, y & $29.0(26.0-30.0)$ & $29.2 \pm 5.9$ \\
$\begin{array}{l}\text { Body mass index }{ }^{\mathrm{a}} \\
\text { Duration of the 2nd stage } \\
\text { of labor, min }\end{array}$ & $35.5(26.1-32.2)$ & $29.8 \pm 4.3$ \\
Head circumference, cm & $34.5(33.9-35.1)$ & $37.8 \pm 27.2$ \\
Perineal trauma, degrees & $1(0-1)$ & $34.5 \pm 1.2$ \\
Neonatal weight, g & $3560(3418-3875)$ & $3549 \pm 378$ \\
Apgar score at 1 min & $9(9-10)$ & $9.1 \pm 0.9$ \\
Apgar score at 5 min & $10(9-10)$ & $9.7 \pm 0.6$ \\
Neonatal pH & $7.29(7.26-7.36)$ & $7.29 \pm 0.09$ \\
\hline
\end{tabular}

${ }^{a}$ Calculated as weight in kilograms divided by the square of height in meters
Table 2 MPP measurement data

\begin{tabular}{|c|c|c|c|c|}
\hline MPP variable & Accoucheur & Mean \pm SD & $\begin{array}{l}\text { Median } \\
\text { (interquartile range) }\end{array}$ & $p^{a}$ \\
\hline \multirow[t]{3}{*}{ Duration, $\mathrm{s}$} & Overall & $13.6 \pm 8.2$ & $13.6(8.8-15.4)$ & \\
\hline & A 1 & $12.5 \pm 5.7$ & $12.5(10.3-14.1)$ & \multirow[t]{2}{*}{.76} \\
\hline & A 2 & $14.7 \pm 10.4$ & $14.1(6.9-17.2)$ & \\
\hline \multirow{3}{*}{$\begin{array}{l}\text { Thumb mean } \\
\text { force, } N\end{array}$} & Overall & $26.7 \pm 6.8$ & $26.1(20.3-31.8)$ & \multirow{3}{*}{.008} \\
\hline & A 1 & $30.5 \pm 6.5$ & $30.0(26.7-34.8)$ & \\
\hline & A 2 & $22.9 \pm 4.8$ & $21.9(19.3-25.6)$ & \\
\hline \multirow{3}{*}{$\begin{array}{l}\text { Index finger } \\
\text { mean } \\
\text { force, N }\end{array}$} & Overall & $25.5 \pm 5.7$ & $26.8(22.0-29.6)$ & \multirow{3}{*}{.06} \\
\hline & A 1 & $27.7 \pm 5,7$ & $28.3(26.3-30.0)$ & \\
\hline & A 2 & $23.3 \pm 5.0$ & $22.3(21.8-26.8)$ & \\
\hline \multirow{3}{*}{$\begin{array}{l}\text { Middle finger } \\
\text { mean } \\
\text { force, N }\end{array}$} & Overall & $20.2 \pm 7.8$ & $20.5(13.7-26.2)$ & \multirow{3}{*}{.23} \\
\hline & A 1 & $18.1 \pm 7.7$ & $20.2(11.9-24.2)$ & \\
\hline & A 2 & $22.2 \pm 7.8$ & $23.1(14.5-27.8)$ & \\
\hline \multirow{3}{*}{$\begin{array}{l}\text { Thumb } \\
\text { maximum } \\
\text { force, N }\end{array}$} & Overall & $34.3 \pm 7.2$ & $35.1(28.6-38.7)$ & \multirow{3}{*}{.03} \\
\hline & A 1 & $37.8 \pm 7.0$ & $38.1(32.5-42.5)$ & \\
\hline & A 2 & $30.9 \pm 5.7$ & $29.8(25.7-35.9)$ & \\
\hline \multirow{3}{*}{$\begin{array}{l}\text { Index finger } \\
\text { maximum } \\
\text { force, N }\end{array}$} & Overall & $32.6 \pm 6.6$ & $33.1(27.3-38.6)$ & \multirow{3}{*}{.17} \\
\hline & A 1 & $34.6 \pm 5.7$ & $33.9(32.3-38.4)$ & \\
\hline & A 2 & $30.4 \pm 7.0$ & $27.9(25.5-37.1)$ & \\
\hline \multirow{3}{*}{$\begin{array}{l}\text { Middle finger } \\
\text { maximum } \\
\text { force, N }\end{array}$} & Overall & $27.6 \pm 10.1$ & $27.0(21.8-33.0)$ & \multirow{3}{*}{.20} \\
\hline & A 1 & $23.9 \pm 8.7$ & $24.7(18.6-31.5)$ & \\
\hline & A 2 & $31.2 \pm 10.6$ & $29.7(24.4-39.0)$ & \\
\hline
\end{tabular}

A1 Accoucher 1, A2 Accoucher 2

${ }^{a}$ non-parametric ANOVA (2-sample Kruskal-Wallis test) of medians

variation in the forces applied by the individual practitioners in the different births (Table 2, Fig. 2).

Irrespective of the accoucheur, there were strong correlations between mean and maximum forces of the thumb (0.95), index finger (0.91) and middle finger $(0.89)$.

\section{Discussion \\ Main findings}

In this study we were able to quantify, in real time, the forces executed by two independent accoucheurs at the time of FMPP. The bespoke system enabled us to capture data for the extent of pressure applied by the thumb, index and middle fingers during the intervention and to assess the inter- and intra-practitioner variability in performing MPP. The duration of the active FMPP intervention was shorter than our expectation where in 6 births $(30.0 \%)$ it lasted $<10$ s and in $4(20.0 \%)$ births the intervention took $<5 \mathrm{~s}$. This highlights the importance of the timing and precision by which FMPP must be executed to ensure its effectiveness during fetal head expulsion. In the majority of deliveries the thumb, index and middle fingers activity started almost simultaneously with the maximum forces applied at a median 


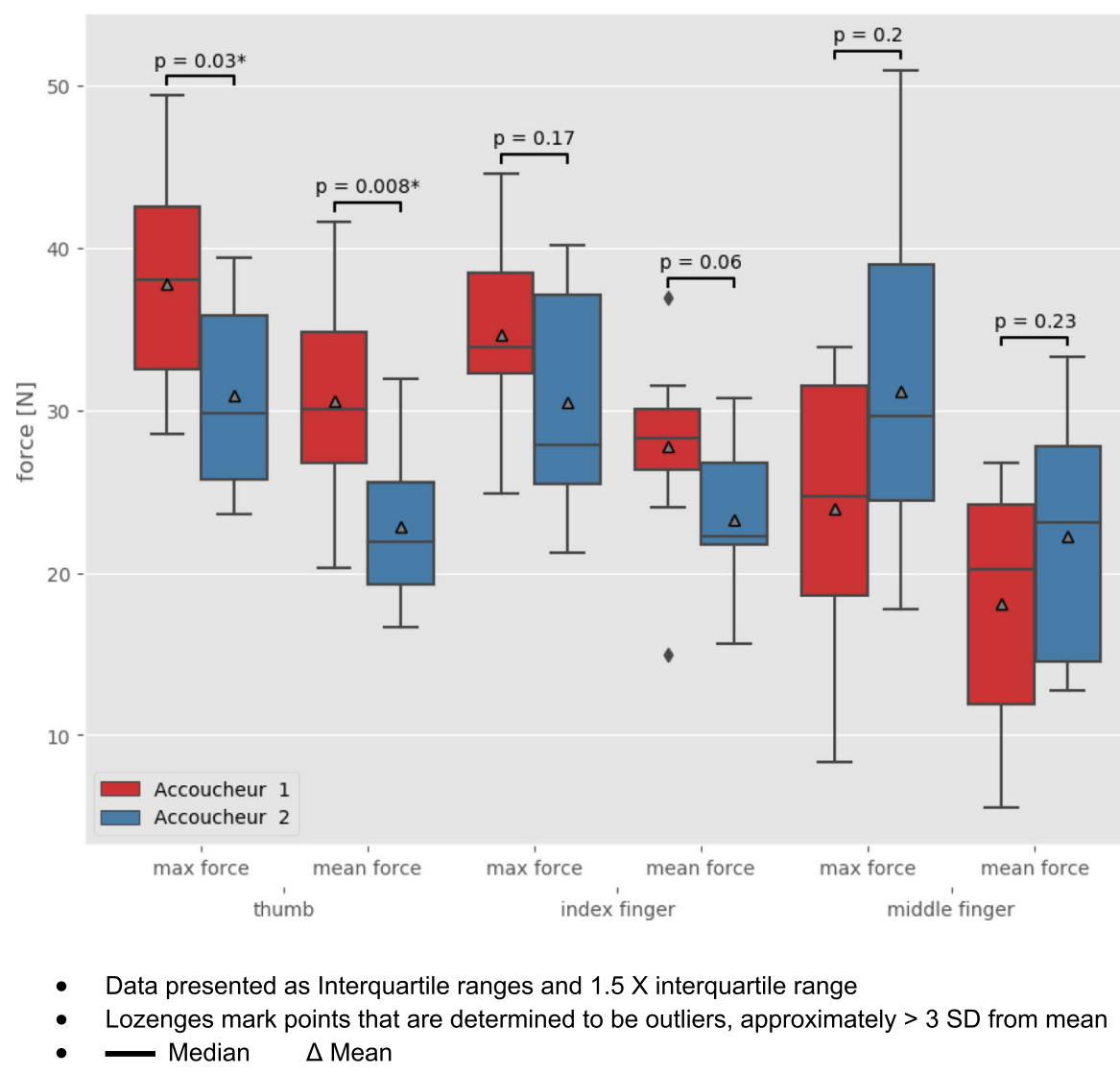

Fig. 2 Mean and maximum forces applied by the thumb, index and middle fingers

of 5.7-5.9 s after FMPP initiation. Interestingly data relating to the duration of the active intervention and the interaction between its components was fairly consistent amongst the 2 practitioners and in the different births. Moreover, apart from thumb measurements, there were no significant differences in the force applied by the index and middle fingers between the participating obstetricians. Although not formally assessed in the study, it is possible that the observed differences in thumb measurements are a reflection of the heterogeneity of maternal, fetal and labor related factors that influence the birth process. Many of these variables, like the strength of the uterine contraction or maternal pushing, are not easily quantifiable to perform an adequate scientific evaluation. It is also possible that this variation reflects the actual differences in how practitioners perform the technique. This is potentially important because it could be linked to variation in reported effectiveness of the intervention.

\section{Comparison to other studies}

Our group has previously demonstrated that, during FMPP, the optimal placement of the thumb and index finger is $2 \mathrm{~cm}$ anterior of the fourchette and $12 \mathrm{~cm}$ apart.
While the most effective distance and direction of movement is to approximate these digits by a distance of 1 $\mathrm{cm}$ on either side without changing their anteroposterior orientation to the fourchette [17, 20, 21, 23]. Additionally, it has been also shown, that an imprecision of just $1 \mathrm{~cm}$ might increase the maximum strain at the perineum by up to $30 \%$ [20]. This highlights the potential magnitude of the effect of, what could be perceived, as a subtle variation in technique performance. To our knowledge this is the first study of the metrics of manual perineal support. We believe that this information will complement the findings of our previous studies in the field. Indeed, the results obtained provide useful information that will feed into our refined computational model with the aim of refining the technique to maximize its effectiveness. This will ultimately provide invaluable information for structured training programs and clinical practice [24].

\section{Strengths and limitations}

We recognize that some aspects of this work can be perceived as limitations. Firstly, we only captured data from two practitioners. However, because our primary intention was to use this information as a benchmark to feed into 
our computational model, it was essential for us to gather data from senior obstetricians, experienced in performing FMPP and fully aware of its components. In addition, this allowed us to evaluate the intra-practitioner variability. Secondly, we are aware that our sample size is fairly small. Nevertheless, we mainly wanted to collect pilot data on the range of forces applied when performing this technique and the timings related to the active intervention. In contrast, the development of a specifically designed integrated system to capture the required data and the fact that this is the first report of such measurements are major strengths of our study.

\section{Conclusion}

The duration of active application of MPP at the time of head expulsion lasted for only a very short duration. In the majority of cases the thumb and fingers actions start simultaneously. To our knowledge this is the first study quantifying the forces of the accoucheur's fingers on the perineum as well the duration of MPP itself and the timely involvement of the middle finger of the dominant hand. The results obtained are important to improve the numerical modeling of MPP in order to produce more realistic data.

\section{Abbreviations}

FMPP: Finnish technique of manual perineal protection; MG: Measurement glove; MPP: Manual perineal protection

\section{Acknowledgements}

Not applicable.

\section{Authors' contributions}

VK: Project development, Literature search, Data collection, Manuscript writing. ZR: Project development, Literature search, Data collection, Manuscript editing and revision. LH: Project development, Manuscript editing and revision. TZ: Data collection and analysis, Manuscript editing and revision. DT: Glove design and production, Data collection, Manuscript editing and revision. KMl: Literature search, Manuscript writing, editing and revision. All authors have read and approved the manuscript.

\section{Funding}

This work was supported by the project n. 182 'Obstetrics 2.0 - Virtual models for the prevention of injuries during childbirth" realised within the frame of the Program INTERREG V-A: Cross-border cooperation between the Czech Republic and the Federal State of Germany, Bavaria, Aim European Cross-border cooperation 2014-2020. The realisation is supported by financial means of the European Regional Development Fund (85\% of the costs) and the state budget of the Czech Republic (5\%). This funding covered the cost of developing the measurement gloves and the integration to the computer system as well as researchers' time for their involvement in the study. $\mathrm{Kl}$ is part-funded by project No. CZ.02.1.01/0.0/0.0/16_019/0000787 "Fighting INfectious Diseases", awarded by the Ministry of Education, Youth and Sports of the Czech Republic, financed from The European Regional Development Fund. Funders were not involved in the design, analysis or the reporting of this work.

\section{Availability of data and materials}

The datasets used and/or analysed during the current study are available from the corresponding author on reasonable request.

\section{Ethics approval and consent to participate}

Ethical approval for the study was granted by Etická komise, FN a LF UK v Plzni, Edvarda Beneše 1128/ 13, 30599 Plzeň on October 4, 2018 Reference number 383/2018. All women signed an informed consent.

\section{Consent for publication}

Not applicable.

\section{Competing interests}

The authors declare that they have no competing interests.

\section{Author details}

'Department of Gynecology and Obstetrics, University Hospital, alej Svobody 76, 30460 Pilsen, Czech Republic. ${ }^{2}$ Biomedical Center, Faculty of Medicine in Pilsen, Charles University, Pilsen, Czech Republic. ${ }^{3}$ New Technologies Research Centre, University of West Bohemia, Pilsen, Czech Republic.

Received: 9 April 2020 Accepted: 1 June 2020

Published online: 11 June 2020

\section{References}

1. Fodstad K, Staff AC, Laine K. Sexual activity and dyspareunia the first year postpartum in relation to degree of perineal trauma. Int Urogynecol J. 2016; 27:1513-23. https://doi.org/10.1007/s00192-016-3015-7.

2. Necesalova P, Karbanova J, Rusavy Z, Pastor Z, Jansova M, Kalis V. Mediolateral versus lateral episiotomy and their effect on postpartum coital activity and dyspareunia rate 3 and 6 months postpartum. Sex Reprod Healthc. 2016;8:25-30. https://doi.org/10.1016/j.srhc.2016.01.004.

3. Laine K, Skjeldestad FE, Sandvik L, Staff AC. Prevalence and risk indicators for anal incontinence among pregnant women. ISRN Obstet Gynecol. 2013; 2013:1-8. https://doi.org/10.1155/2013/947572.

4. Aglialoro M. The contribution of the Salerno School to the historical evolution of protection and suturing of the perineum in labor. Minerva Med. 1970;61:5201-3.

5. De Wees WB. Relaxation and management of the perineum during parturition. J Am Med Assoc. 1889;XIII:804. https://doi.org/10.1001/jama. 1889.02401190010002C.

6. Ismail KMK, Paschetta E, Papoutsis D, Freeman RM. Perineal support and risk of obstetric anal sphincter injuries: a Delphi survey. Acta Obstet Gynecol Scand. 2016;94:165-74

7. McCandlish R, Bowler U, Asten H, Berridge G, Winter C, Sames L, et al. A randomised controlled trial of care of the perineum during second stage of normal labour. BJOG. 1998;105:1262-72. https://doi.org/10.1111/j.1471-0528. 1998.tb10004.x.

8. Mayerhofer K, Bodner-Adler B, Bodner K, Rabl M, Kaider A, Wagenbichler P, et al. Traditional care of the perineum during birth. A prospective, randomized, multicenter study of 1,076 women. J Reprod Med. 2002;47: 477-82 http://www.ncbi.nlm.nih.gov/pubmed/12092017.

9. Bulchandani S, Watts E, Sucharitha A, Yates D, Ismail K. Manual perineal support at the time of childbirth: a systematic review and meta-analysis. BJOG. 2015;122:1157-65. https://doi.org/10.1111/1471-0528.13431.

10. Naidu M, Sultan AH, Thakar R. Reducing obstetric anal sphincter injuries using perineal support: our preliminary experience. Int Urogynecol J. 2017; 28:381-9. https://doi.org/10.1007/s00192-016-3176-4.

11. Jangö H, Langhoff-Roos J, Rosthøj S, Sakse A. Modifiable risk factors of obstetric anal sphincter injury in primiparous women: a population-based cohort study. Am J Obstet Gynecol. 2014;210(1):59.e1-6.

12. Laine K, Rotvold W, Staff AC. Are obstetric anal sphincter ruptures preventable?- large and consistent rupture rate variations between the Nordic countries and between delivery units in Norway. Acta Obstet Gynecol Scand. 2013;92:94-100. https://doi.org/10.1111/aogs.12024.

13. Hals E, Øian P, Pirhonen T, Gissler M, Hjelle S, Nilsen EB, et al. A multicenter interventional program to reduce the incidence of anal sphincter tears. Obstet Gynecol. 2010;116:901-8. https://doi.org/10.1097/AOG. Ob013e3181eda77a.

14. Laine K, Pirhonen T, Rolland R, Pirhonen J. Decreasing the incidence of anal sphincter tears during delivery. Obstet Gynecol. 2008;111:1053-7. https://doi. org/10.1097/AOG.0b013e31816c4402.

15. Stedenfeldt M, Øian P, Gissler M, Blix E, Pirhonen J. Risk factors for obstetric anal sphincter injury after a successful multicentre interventional programme. BJOG. 2014;121:83-91. https://doi.org/10.1111/1471-0528.12274. 
16. Laine K, Skjeldestad FE, Sandvik L, Staff AC. Incidence of obstetric anal sphincter injuries after training to protect the perineum: cohort study. BMJ Open. 2012;2:e001649. https://doi.org/10.1136/bmjopen-2012-001649.

17. Jansova M, Kalis V, Rusavy Z, Zemcik R, Lobovsky L, Laine K. Modeling manual perineal protection during vaginal delivery. Int Urogynecol J. 2014; 25:65-71. https://doi.org/10.1007/s00192-013-2164-1.

18. Kleprlikova H, Kalis V, Lucovnik M, Rusavy Z, Blaganje M, Thakar R, et al. Manual perineal protection: the know-how and the know-why. Acta Obstet Gynecol Scand. 2020;99:445-50. https://doi.org/10.1111/aogs.13781.

19. Kleprlikova H, Kalis V, Lucovnik M, Rusavy Z, Blaganje M, Thakar R, et al. Slowing of fetal head descent is an integral component of manual perineal protection. Acta Obstet Gynecol Scand. 2020;99:558-9. https://doi.org/10. 1111/aogs.13799.

20. Jansova M, Kalis V, Lobovsky L, Hyncik L, Karbanova J, Rusavy Z. The role of thumb and index finger placement in manual perineal protection. Int Urogynecol J. 2014;25:1533-40. https://doi.org/10.1007/s00192-014-2425-7.

21. Jansova M, Kalis V, Rusavy Z, Räisänen S, Lobovsky L, Laine K. Fetal head size and effect of manual perineal protection. PLoS One. 2017;12:e0189842. https://doi.org/10.1371/journal.pone.0189842.

22. Tolar D, Bischofová R, Hynčík L, Gallo J. Wireless system for monitoring body temperature. In: IFMBE Proceedings; 2015. p. 150-3. https://doi.org/10.1007/ 978-3-319-19452-3 40.

23. Zemčík R, Karbanova J, Kalis V, Lobovský L, Jansová M, Rusavy Z Stereophotogrammetry of the perineum during vaginal delivery. Int J Gynecol Obstet. 2012;119:76-80. https://doi.org/10.1016/j.ijgo.2012.05.018.

24. Ali-Masri H, Hassan S, Fosse E, Zimmo KM, Zimmo M, Ismail KMK, et al. Impact of electronic and blended learning programs for manual perineal support on incidence of obstetric anal sphincter injuries: a prospective interventional study. BMC Med Educ. 2018;18:258. https://doi.org/10.1186/ s12909-018-1363-3.

\section{Publisher's Note}

Springer Nature remains neutral with regard to jurisdictional claims in published maps and institutional affiliations.

Ready to submit your research? Choose BMC and benefit from:

- fast, convenient online submission

- thorough peer review by experienced researchers in your field

- rapid publication on acceptance

- support for research data, including large and complex data types

- gold Open Access which fosters wider collaboration and increased citations

- maximum visibility for your research: over $100 \mathrm{M}$ website views per year

At $\mathrm{BMC}$, research is always in progress.

Learn more biomedcentral.com/submissions 